It is hoped that, in the future, reports will be supplied to H.M. Stationery Office as and when they are declassified, and no special announcements will be made; information as to the latest reports available would then be obtained from the regular announcements from H.M. Stationery Office.

\begin{tabular}{|c|c|c|c|c|}
\hline $\begin{array}{l}\text { B.D.D.A. } \\
\text { No. }\end{array}$ & $\begin{array}{l}\text { Report } \\
\text { No. }\end{array}$ & Title and Author(s) & Date & Price \\
\hline 99 & Br. 10 & $\begin{array}{l}\text { Organic derivatives of U. } \\
\text { N. Haworth }\end{array}$ & & 28. $8 d$. \\
\hline 100 & Br. 18 & $\begin{array}{l}\text { Uranyl fluoride. Miscel- } \\
\text { laneous notes. Note No. } \\
\text { 8. The adsorption of at- } \\
\text { mospheric molsture by } \\
\text { anhydrous UF. A. M. } \\
\text { Roberts }\end{array}$ & $\begin{array}{l}\text { Feb. } 16, \\
1942\end{array}$ & 28. $0 d$. \\
\hline 101 & Br. 174 & $\begin{array}{l}\text { Investigation of the Pres- } \\
\text { sure-density relationship } \\
\text { for the hexafluoride of } 0 \\
\text { at } 49 \cdot 2^{\circ} \text { C. C. B. Amph- } \\
\text { lett and } \mathrm{L} \text {. F. Thomas }\end{array}$ & $\begin{array}{l}\text { Feb. 28, } \\
1042\end{array}$ & 28. Od. \\
\hline 102 & Br. 27 & $\begin{array}{l}\text { Uranyl fluoride. Miscel- } \\
\text { laneous notes. Note No. } \\
\text { 18. The true and packing } \\
\text { densities of anhydrous } \\
\text { UF. A. M. Roberts, } \\
\text { B. G. Harvey }\end{array}$ & $\begin{array}{l}\text { Mar. 30, } \\
1942\end{array}$ & 18. $4 d$. \\
\hline 103 & Br. 36 & $\begin{array}{l}\text { The reduction of UF, by } \\
\text { hydrogen. J. Ferguson }\end{array}$ & $\underset{1942}{\operatorname{May} 14}$ & 48. $0 d$. \\
\hline 104 & Br. 182 & $\begin{array}{l}\text { Pressure density relation- } \\
\text { ship for UF, at } 50^{\circ} \text { C.; } \\
\text { revised figure for } \\
\left(\frac{\partial e}{\partial p}\right)-50^{\circ} \text {. C. B. Amph- }\end{array}$ & $\begin{array}{c}1942 \\
\text { June } 30 \\
1942\end{array}$ & 28. $0 d$. \\
\hline 105 & Br. 186 & $\begin{array}{l}\text { lett } \\
\text { The vapour pressure of } \\
\text { UF } \text { from } 12^{\circ} \text { to } 50^{\circ} \mathrm{C} \text {. } \\
\text { C. B. Amphlett }\end{array}$ & $\begin{array}{l}\text { June } 30 \\
1942\end{array}$ & 28. $0 d$. \\
\hline 106 & Br. 187 & $\begin{array}{l}\text { Determination of the va- } \\
\text { pour density of } \mathrm{UF}_{\mathrm{g}} \text { at } \\
\text { room temperature. C. B. } \\
\text { Amphlett and L. F. } \\
\text { Thomas }\end{array}$ & $\underset{1942}{\text { June }} 30$ & 18. $4 d$. \\
\hline 107 & Br. 222 & $\begin{array}{l}\text { The analysis of gaseous } \\
\text { fluorine, Part } \mathbf{I} \text {. The de- } \\
\text { termination of total and } \\
\text { free fluorine. } \\
\text { Williams } \mathbf{F} \text {. }\end{array}$ & $\underset{1942}{\text { Sept. }}$ & 78. $4 d$. \\
\hline 108 & Br. 188 & $\begin{array}{l}\text { Determination of the ultra- } \\
\text { violet absorption of } \\
\text { UF. vapour. A. E. Mar- } \\
\text { tin and C. B. Amphlett }\end{array}$ & $\begin{array}{l}\text { Nov. } 30, \\
1942\end{array}$ & 28. $0 d$. \\
\hline 109 & Br. 166 & $\begin{array}{l}\text { Gland experiment. H. S. } \\
\text { Arms }\end{array}$ & $\begin{array}{l}\text { Jan. 20, } \\
1943\end{array}$ & 88. $8 d$. \\
\hline 110 & Br. 167 & $\begin{array}{l}\text { Fxperiments on the pres- } \\
\text { sure dependence of heat } \\
\text { conductivity concentra- } \\
\text { tion meters. A. F. Brown }\end{array}$ & $\underset{1943}{\operatorname{Mar}}$ & 68. $8 d$. \\
\hline 111 & Br. 242 & $\begin{array}{l}\text { Absolute calibration of a } \\
\text { neutron source. } \mathbf{O} \text {. } \mathbf{R} \text {. } \\
\text { Frisch }\end{array}$ & $\begin{array}{l}\text { June } \\
1943\end{array}$ & 58. $4 d$. \\
\hline 112 & Br. $280 \mathrm{~A}$ & $\begin{array}{l}\text { Remarks on some physical } \\
\text { properties of uranium } \\
\text { metal. F. E. Simon }\end{array}$ & $\underset{1943}{\text { Aug. 16, }}$ & 88. Od. \\
\hline 113 & Br. 281 & $\begin{array}{l}\text { The viscosity of gaseous } \\
\text { fluorine. Critical litera. } \\
\text { ture survey. Rudge and } \\
\text { Southam }\end{array}$ & $\underset{1943}{\text { Aug. } 23,}$ & 68. Od. \\
\hline 114 & Br. 315 & $\begin{array}{l}\text { Notes on Br. } 44 \text { "On the } \\
\text { Correction for Self-Ab- } \\
\text { sorption in } \beta \text {-Ray Meas- } \\
\text { urements", Broda, Guer- } \\
\text { on and Kowarski, 1942. } \\
\text { N. Feather }\end{array}$ & Aug. 16 & 68. $0 d$. \\
\hline 115 & Br. 425 & $\begin{array}{l}\text { Determination of } U^{\text {sas }} \text { con- } \\
\text { tent of enriched uranium } \\
\text { samples. E. Bretscher } \\
\text { and E. B. Martin }\end{array}$ & $\begin{array}{l}\text { Nov. 3, } \\
1943\end{array}$ & 28. Od. \\
\hline 116 & Br. $397 \mathrm{~A}$ & $\begin{array}{l}\text { Memorandum on American } \\
\text { tests on fluorocarbon lube } \\
\text { oils. J. R. Park }\end{array}$ & $\underset{1944}{\text { Mar. 16, }}$ & 18. $4 d$. \\
\hline 117 & Br. 516 & $\begin{array}{l}\text { A hard valve pulse analyser. } \\
\text { M. I. Poole }\end{array}$ & $\underset{1944}{\operatorname{May} 7}$ & 128. $0 d$. \\
\hline 118 & BI. 37 & $\begin{array}{l}\text { Stability of solutions of } \\
\mathrm{UCl} \text { in alcohol, acetone, } \\
\text { and water. C. B. Amph- } \\
\text { lett }\end{array}$ & $\begin{array}{l}\text { May } 31 \\
1944\end{array}$ & 28. $0 d$. \\
\hline 119 & Br. 673A & $\begin{array}{l}\text { The analysis of nitrogen - } \\
\text { argon mixtures. P. A. I. } \\
\text { Tahourdin }\end{array}$ & $\underset{1945}{\text { Dec. } 7 \text {, }}$ & 4s. $8 d$. \\
\hline 120 & Br. 718A & $\begin{array}{l}\text { The tensile properties of } \\
\text { uranium at elevated tem- } \\
\text { peratures in the } \alpha \text {-range. } \\
\text { National Physical Lab- } \\
\text { oratory }\end{array}$ & $\underset{1946}{\text { Mar. }}$ & 18. $4 d$. \\
\hline 121 & Br. 775 & $\begin{array}{l}\text { Preliminary creep tests on } \\
99 \cdot 8 \% \text { aluminium at } \\
300^{\circ}, 350^{\circ} \text { and } 400^{\circ} \mathrm{C} \text {. } \\
\text { British Non-Ferrous Met- } \\
\text { als Research Association }\end{array}$ & July 1947 & 68. $8 d$. \\
\hline
\end{tabular}

\section{FORESTRY IN TRINIDAD AND TOBAGO}

THE present forest policy for the Colony of Trinidad and Tobago has had several predecessors. The Annual Forest Administration Report for the Year 1946, written by Mr. John Carter, acting conservator of forests, starts with a statement on the present forest policy formulated in 1942 and now formally accepted by the Government and the Secretary of State for the Colonies. Briefly sum. marized, it is as follows : (a) Permanent reservation by the Crown of suitably situated areas of forest of a total acreage sufficient to supply the objects aimed at, both direct and indirect. (b) Management of reserved forests on the basis of a sustained yield. (c) The fullest utilization of the forest products, based on the correct forest management and the most economic utilization of imported lumber. (d) Organised research in all branches of forestry. (e) A fully trained staff, both gazetted and subordinate, and the education of all classes of the com. munity to understand the benefits of forestry. (f) The encouragement of, and assistance to, private forestry. (g) Co-operation between forestry and other land interests with the object of bringing into force a sound land utilization policy.

These are good clauses in a correct forest policy. They have been enunciated on more or less similar lines many times in the past in the British Empire. It would appear from the action being taken both in the Empire and outside it in other parts of the world that Governments generally have become conscious of the serious dangers which are threatening their populations through wasteful utilization of the forest resources, involving possible wood famines in certain regions of the globe, and seriously increasing erosion and degradation of soils and interference with water supplies and rainfall.

The present report describes the steps being taken in carrying out the resolutions on the above heads of policy. The report then continues with details on the actual work carried out during the year. Among other points the question of game preservation and the difficulty of control in the close season is men. tioned : and also that negotiations were continued with the Trinidad Field Naturalists Club with a view to the formation of a zoological society which would undertake to establish and maintain a zoological 'garden'. It is interesting to note that a site of about 6 acres in the Royal Botanic Gardens has been made available for the proposed zoo, and the Government has agreed to hand over to a zoological society when it is formed the funds standing to the credit of the Wild Birds Fund, and an annual grant equal to the amount collected for hunting licences.

\section{FORTHCOMING EVENTS}

(Meetings marked with an asterisk * are open to the public)

Monday, January 26

Royat SOcIRTy of ARTs (at John Adam Street, Adelphi, Iondon, W.C.2), at 4.30 p.m.-Dr. C. H. Andrewes, F.R.S.: "The Common Cold" (Cantor Lecture).

UNIVRRSITY COLLEG L LONDON (in the Physiology Theatre, Gower Street, London, W.C.1), at 4.45 p.m.-Dr. Ernest Baldwin: "The Comparative Biochemistry of Respiration and Metabolism". (Further Lectures on February 2, 9, 16, 23 and March 1.)*

MaNCHESTHR Literary aND PHIlosophical SOCIETY (in the Reynolds Hall, College of Technology, Manchester), at 5.30 p.m.-Sir George Thomson, F.R.S.: "Determinism in the Physical World" (Joule Memorial Lecture).* 